\title{
O CASO EIKE BATISTA, O INSIDER TRADING E A VIOLAÇÃO AO SISTEMA BRASILEIRO DE DEFESA DA CONCORRÊNCIA
}

\section{THE EIKE BATISTA CASE, INSIDER TRADING AND THE BREACH OF THE BRAZILIAN COMPETITION DEFENSE SYSTEM}

\begin{abstract}
WAGNER ANDRÉ JOHANSSON
Mestrando - Centro Universitário Curitiba - UNICURITIBA. Especialista pela EMAP/PR, advogado em Curitiba - PR. E-mail: wagner.advocacia@gmail.com
\end{abstract}

\section{RESUMO}

O presente resumo tem por finalidade apresentar levantamento bibliográfico com a finalidade de levantar se o empresário Eike Batista, dono da empresa OGX praticou conduta possível de ser considerada como violadora do Artigo 36 e seus incisos e parágrafos da Lei 12.529/2011 - lei que institui o Sistema Brasileiro de Defesa da Concorrência. Esta lei busca prevenir e repreender infrações contra a ordem econômica. A Constituição Federal de 1988 prevê a proteção à livre concorrência em seu Artigo 170, IV, ao tratar da Ordem Econômica. Desde 1994, ano de criação da OMC, com o Tratado de Marrakesh, o mundo globalizado passa a prestar mais atenção às condutas dos atores no comércio Internacional. Em recente decisão, o empresário brasileiro Eike Batista foi condenado pela CVM ao pagamento de multas somadas no valor de $\mathrm{R} \$ 536$ milhões por vender ações de sua empresa lucrando com o uso de informações privilegiadas, gerando graves prejuízos a investidores, o que se denomina insider trading. Nas palavras da Prof Dra Viviane Sellos Knoer: "No mercado de capitais, desde há muito, a previsão legislativa do full disclosure significou a imposição do dever de informar em relação aos acontecimentos que possam influir 
Personalidade Acadêmica Homenageada:

Raymundo Juliano Feitosa (Universidade Federal do Rio Grande do Norte - UFRN)

em seu funcionamento. Daí a proibição do uso de informações reservadas, insider trading, cujo resultado acarretaria a distorção dos mecanismos de mercado." Henrique Machado - diretor da CVM - declarou que as condutas do empresário violam gravemente o mercado de capitais, fulminando a confiança de investidores. Andre Esteves, do Banco BTG, declarou à Reuters que parte da culpa pela derrocada foi pela política do governo Dilma que não ouvia os conselhos do mercado, gerando incerteza sobre os rumos do país. A falta de racionalidade e transparência impede o avanço nos negócios, completa o banqueiro. A defesa do empresário nega as acusações. Segundo Eike, as transações foram feitas para quitar as obrigações contratuais com investidores estrangeiros. Os advogados do empresário vão recorrer da decisão, por entenderem que não ficou provado que o empresário teria agido com o objetivo de lucrar nas transações. A julgar conflito de competência, sob numero 135749, O Ministro Dr. Arnaldo Esteves Lima do STJ relata: "mostra-se claro que a conduta delituosa prevista no seu art. 27-D da Lei n. 6.385/76 afeta diretamente o interesse da União, porquanto a utilização de informação privilegiada pode gerar lesão ao Sistema Financeiro Nacional, ao pôr em risco a confiabilidade dos investidores no mercado de capitais, aniquilando a confiança e a lisura de suas atividades." $O$ fato é que, data máxima vênia ao entendimento dos procuradores do empresário, possível se concluir que o Sr Eike praticou o insider trading, o que pode ser encarado como violação a vários incisos do Artigo 36 do SBDC. No resumo, a lesão ao SFN promovida por Elke (insider trading) deve ser considerada uma infração contra a ordem econômica.

PALAVRAS-CHAVE: Mercado de capitais; livre concorrência; insider trading; SBDC.

\section{REFERÊNCIAS}

BRASIL. Constituição (1988). Constituição: República Federativa do Brasil. Brasília, DF: Senado Federal, 1988 
Personalidade Acadêmica Homenageada:

Raymundo Juliano Feitosa (Universidade Federal do Rio Grande do Norte - UFRN)

<http://www.cvm.gov.br/export/sites/cvm/noticias/anexos/2019/20190527_PAS_CVM _RJ2014_578_voto_diretor_henrique_machado.pdf>. Acesso em 30/05/2019.

CVM condena Eike Batista por lucrar com informação privilegiada. Disponível em: <https://www.poder360.com.br/justica/cvm-condena-eike-batista-por-manipularinformacoes-e-lucrar-no-mercado/>. Acesso em 30/05/2019.

Eike Batista é condenado a pagar R\$ 536 mi por uso de informação privilegiada na OGX InfoMoney Veja mais em: <https://www.infomoney.com.br/mercados/acoes-eindices/noticia/8347470/eike-batista-e-condenado-a-pagar-r-536-mi-por-uso-deinformacao-privilegiada-na-ogx>. Acesso em 30/05/2019.

KNOER, Viviane Sellos. Vinte anos da política nacional das relações de consumo e o reconhecimento da dignidade humana a partir da pessoa do consumidor .<revista.unicuritiba.edu.br/index.php/RevJur/article/download/214/187>. Acesso em 30/05/2019.

BRASIL. Lei 6.385 de 7 de DEZEMBRO de 1976. Dispõe sobre o mercado de valores mobiliários e cria a Comissão de Valores Mobiliários.<http://www.planalto.gov.br/ccivil_03/leis/16385.htm> Acesso em 30/05/2019.

BRASIL. Lei 12.529 de 30 de novembro de 2011. Estrutura o Sistema Brasileiro de Defesa da Concorrência; dispõe sobre a prevenção e repressão às infrações contra a ordem econômica;..OMISSIS..e dá outras providências<http://www.planalto.gov.br/CCivil_03/_Ato20112014/2011/Lei/L12529.htm>. Acesso em 28 de maio de 2019.

MINISTERIO PÚBLICO FEDERAL. <http://www.mpf.mp.br/atuacaotematica/ccr2/publicacoes/boletins/documentos/boletins-

2016/comunicado_24/voto_8369.pdf/>. Acesso em 30/05/2019.

- BTG Pactual diz que não suporta pesadas perdas para credores da EBX.<https://www.reuters.com/article/brazil-pactual-ebxidUSL1NOFQ0AY20130720>.. Acesso em 29/05/2019.

SUPERIOR TRIBUNAL DE JUSTIÇA. $<$ http://www.stj.jus.br/SCON/jurisprudencia/toc.jsp?livre=135749\&b=ACOR\&thesauru $\mathrm{s}=J$ JURIDICO\&p=true $>$ Acesso em 30/05/2019. 